\title{
Atmospheric transport and deposition of Indonesian volcanic emissions
}

\author{
M. A. Pfeffer ${ }^{1}$, B. Langmann ${ }^{1}$, and H.-F. Graf ${ }^{2}$ \\ ${ }^{1}$ Department of the Atmosphere in the Earth System, Max-Planck-Institute for Meteorology, Hamburg, Germany \\ ${ }^{2}$ Department of Geography, University of Cambridge, Cambridge, UK
}

Received: 6 September 2005 - Published in Atmos. Chem. Phys. Discuss.: 21 November 2005

Revised: 2 March 2006 - Accepted: 8 May 2006 - Published: 30 June 2006

\begin{abstract}
A regional climate model has been used to study the transport and deposition of sulfur $\left(\mathrm{SO}_{2}\right.$ and $\left.\mathrm{SO}_{4}^{2-}\right)$ and $\mathrm{PbCl}_{2}$ emissions from Indonesian volcanoes. The sensitivity of the atmospheric loss of these trace species to meteorological conditions and their solubility was examined. Two experiments were conducted: 1) volcanic sulfur released as primarily $\mathrm{SO}_{2}$ and subject to transport, deposition, and oxidation to $\mathrm{SO}_{4}^{2-}$; and 2) $\mathrm{PbCl}_{2}$ released as an infinitely soluble passive tracer subject to only transport and deposition. The first experiment was used to calculate $\mathrm{SO}_{2}$ loss rates from each active Indonesian volcano producing an annual mean loss rate for all volcanoes of $1.1 \times 10^{-5} \mathrm{~s}^{-1}$, or an e-folding rate of approximately 1 day. $\mathrm{SO}_{2}$ loss rate was found to vary seasonally, be poorly correlated with wind speed, and uncorrelated with temperature or relative humidity. The variability of $\mathrm{SO}_{2}$ loss rates is found to be correlated with the variability of wind speeds, suggesting that it is much more difficult to establish a "typical" $\mathrm{SO}_{2}$ loss rate for volcanoes that are exposed to changeable winds. Within an average distance of $70 \mathrm{~km}$ away from the active Indonesian volcanoes, 53\% of $\mathrm{SO}_{2}$ loss is due to conversion to $\mathrm{SO}_{4}^{2-}, 42 \%$ due to dry deposition, and 5\% due to lateral transport away from the dominant direction of plume travel. The solubility of volcanic emissions in water is shown to influence their atmospheric transport and deposition. High concentrations of $\mathrm{PbCl}_{2}$ are predicted to be deposited near to the volcanoes while volcanic $\mathrm{S}$ travels further away until removal from the atmosphere primarily via the wet deposition of $\mathrm{H}_{2} \mathrm{SO}_{4}$. The ratio of the concentration of $\mathrm{PbCl}_{2}$ to $\mathrm{SO}_{2}$ is found to exponentially decay at increasing distance from the volcanoes. The more rapid removal of highly soluble species should be considered when observing $\mathrm{SO}_{2}$ in an aged plume and relating this concentration to other volcanic species. An assumption that the ratio between the concentrations of highly soluble
\end{abstract}

Correspondence to: M. A. Pfeffer

(melissa.pfeffer@zmaw.de) volcanic compounds and $\mathrm{SO}_{2}$ within a plume is equal to that observed in fumarolic gases is reasonable at small distances from the volcanic vent, but will result in an underestimation of the emission flux of highly soluble species.

\section{Introduction}

Volcanic emissions can have significant environmental effects on local, regional, and global scales depending on how far the emissions are transported away from source prior to deposition. The impacts of volcanic emissions on the environment are defined by several variable characteristics, such as their chemical and physical properties (including solubility and particle size) (Mather et al., 2003), as well as environmental factors, i.e. volcano latitude, the maximum height at which emissions are injected (Halmer and Schmincke, 2003), wind speed, and precipitation.

Volcanic emissions can be released continuously by passive degassing or mild eruptions and can be released sporadically by more violent, and short-lived, eruptions. Violent eruptions can inject volcanic emissions past the tropopause with generally at least one to two stratosphere-reaching eruptions per year (Simkin, 1993; Bluth et al., 1997). Stratosphere-reaching eruption clouds can cause global surface cooling for months up to a few years by sulfate aerosol $\left(\mathrm{SO}_{4}^{2-}\right)$ backscattering of incoming shortwave solar radiation (e.g. Textor et al., 2003). It was calculated by Andres and Kasgnoc (1998) that only $1 \%$ of volcanic $\mathrm{SO}_{2}$ is released sporadically, while $99 \%$ is released continuously. Continuous, tropospheric emissions are rapidly deposited locally and regionally but can have a significant atmospheric impact because they are supplied for long periods of time, and because volcanoes are often at elevations above the planetary boundary layer, allowing those emissions to remain in the troposphere longer than, for example, most anthropogenic $\mathrm{S}$ emissions. As an example of the relative significance of

Published by Copernicus GmbH on behalf of the European Geosciences Union. 
non-eruptive volcanic degassing, such sources may be responsible for $24 \%$ of the total annual mean direct radiative top-of-atmosphere forcing (Graf et al., 1997).

Volcanic emissions are primarily $\mathrm{H}_{2} \mathrm{O}$, followed by $\mathrm{CO}_{2}$, $\mathrm{SO}_{2}, \mathrm{HCl}$, and other compounds (e.g. Bardintzeff and McBirney, 2000). Some volcanic compounds are particularly environmentally important because they are released in extremely small quantities by other sources. For example, volcanoes may be responsible for $11 \%$ of the total global emissions of $\mathrm{Cr}$, and species including $\mathrm{Hg}, \mathrm{Ni}, \mathrm{Cu}$, and $\mathrm{As}$ each contribute more than 5\% (Nriagu, 1989, corrected by Mather et al., 2003). Considering the volcanic contribution to natural (non-anthropogenic) emissions, species including $\mathrm{Cd}, \mathrm{Ni}, \mathrm{Hg}$, and $\mathrm{Pb}$ contribute more than $15 \%$ to the global natural emissions of each. $\mathrm{SO}_{2}$ has been the most monitored volcanic emission because the concentration of $\mathrm{SO}_{2}$ within a volcanic plume is typically orders of magnitude greater in concentration than what is found in background ambient air. For the past few decades the majority of volcanic $\mathrm{SO}_{2}$ observations have been performed with the Correlation Spectrometer (COSPEC), which measures the flux of emitted $\mathrm{SO}_{2}$ (e.g. Stoiber et al., 1983). The (relatively) large number of published measurements of volcanic $\mathrm{SO}_{2}$ fluxes is a useful tool for assessing the impact of volcanoes on the atmosphere because $\mathrm{SO}_{2}$ is an environmentally important gas. $\mathrm{SO}_{2}$ is readily converted, within days, to $\mathrm{SO}_{4}^{2-}$ aerosol which is climatically significant and is a main component of acid rain.

In addition to ground-based remote sensing (including COSPEC), fumarolic gas sampling and plume particle sampling (e.g. Pfeffer et al., 2006) have contributed to an improved understanding of the variations in time and between different volcanoes of emission compositions and strengths and, to a lesser extent, about processes occurring within volcanic plumes. There are, however, limitations to what can be accomplished in the field. For example, ground-based remote sensing measurements of volcanic $\mathrm{SO}_{2}$ fluxes over time at one volcano can be used to observe changes in volcanic activity as an eruption prediction tool in conjunction with other volcano monitoring techniques (for example at Montserrat; Young et al., 2003). Remote sensing instruments can detect changes in $\mathrm{SO}_{2}$ emissions, but cannot determine unambiguously if the observed variations are due to changes in the volcano itself or to changing meteorological conditions.

Because $\mathrm{SO}_{2}$ flux rates are the most abundant volcanic emission measurements, such observations have been used to extrapolate to other, unmeasured volcanic compounds: " $\mathrm{X}$ ". This is done by relating the observed concentration of $\mathrm{SO}_{2}$ in the plume to the ratio of " $\mathrm{X}$ " to total $\mathrm{S}\left(\mathrm{SO}_{2}+\mathrm{H}_{2} \mathrm{~S}\right)$ found in fumarolic gases or condensates. In fumarolic gases, $\mathrm{S}$ is found as primarily $\mathrm{SO}_{2}$ and $\mathrm{H}_{2} \mathrm{~S}$, and it is assumed that all $\mathrm{S}$ is oxidized immediately upon exposure to air to be found as $\mathrm{SO}_{2}$. The method of relating " $\mathrm{X}$ " to $\mathrm{SO}_{2}$ assumes that the ratio of the concentrations of " $\mathrm{X}$ " to $\mathrm{SO}_{2}$ remains constant from the time the emissions are released until the plume is measured. This technique has been used, for example, to es- timate the annual flux of metals from volcanoes (Hinkley et al., 1999) and to constrain the flux balances of elements at subduction zones (Hilton et al., 2002). The assumption of a steady ratio of $[\mathrm{X}] /\left[\mathrm{SO}_{2}\right]$ remains a subject of uncertainty, however. Pyle and Mather (2003), for example, have shown that $[\mathrm{Hg}] /\left[\mathrm{SO}_{2}\right]$ ratios can vary by an order of magnitude dependent on the type of volcanic activity (passively degassing vs. explosively erupting). The ratio of $[\mathrm{X}] /\left[\mathrm{SO}_{2}\right]$ can vary not only dependent on the type of volcanic activity, but can also vary in time if the two species are removed at different rates from the plume. As remote sensing measurements of $\mathrm{SO}_{2}$ flux using COSPEC are performed at distances of up to $30 \mathrm{~km}$ away from volcanic craters (for example at Mt. Etna; Weibring et al., 2002), it is important to constrain how reasonable it is to relate observations of $\mathrm{SO}_{2}$ in an aged volcanic plume to more soluble compounds.

A field study examining the influence of variable meteorological factors on volcanic sulfur was performed by Fujita et al. (2003). They observed that the wet deposition of $\mathrm{SO}_{4}^{2-}$ and the percentage of sulfur deposited as $\mathrm{SO}_{4}^{2-}$ increased with increasing precipitation. McGonigle et al. (2004) attempted to determine what meteorological parameters are the most important for influencing the loss of $\mathrm{SO}_{2}$ from volcanic plumes by performing repeated scans of $\mathrm{SO}_{2}$ column concentration using ground-based differential optical absorption spectroscopy (DOAS). They measured the plume of Masaya volcano for several days during the dry season and found that time of day (i.e. insolation strength), relative humidity, and temperature had no significant impact on the measured $\mathrm{SO}_{2}$ flux rate. We have addressed the question of the influence of meteorological conditions on volcanic plume $\mathrm{SO}_{2}$ loss using an atmospheric chemistry model. We have exploited this technique to hold the modeled volcanic emissions constant, thus removing the inherent natural variability of volcanic emission rates. This enables us to study what variations in atmospheric transport are due to changing atmospheric conditions rather than due to changes in the volcanic activity. The modeling technique also allows us to study a much longer time period (1 year), consider different seasons, and to perform statistical comparisons between the $\mathrm{SO}_{2}$ loss rate and the varying meteorological conditions. Modeling also enables us to calculate what portion of $\mathrm{SO}_{2}$ lost from the volcanic plume is due to the different loss mechanisms: oxidation, deposition, or transport out of the plume, as well as to consider volcanic emissions additional to $\mathrm{SO}_{2}$. This paper describes a regional atmospheric chemistry modeling study that has been performed to address two questions: 1) How do variable meteorological conditions influence volcanic $\mathrm{SO}_{2}$ concentration in the atmosphere and $\mathrm{SO}_{2}$ loss rates? and 2) How do the transport and deposition patterns of highly soluble volcanic compounds relate to $\mathrm{SO}_{2}$ ? This study has been performed over Indonesia because this is the region of the world with the largest number of historically active volcanoes and the region has a relatively continuous emission 
history with $4 / 5$ of the volcanoes with dated eruptions having erupted here during the past century (Simkin and Siebert, 1994).

\section{Experimental setup}

The regional atmospheric chemistry model REMOTE (Regional Model with Tracer Extension; Langmann, 2000) has been used to simulate meteorological conditions for the year 1985, a climatologically "normal" year, i.e. neither "El Niño" nor "La Niña". REMOTE combines the physics of the regional climate model REMO 5.0 with tropospheric chemical equations for 63 chemical species. The physical and dynamical equations in the model (Jacob, 2001) are based on the regional weather model EM/DM of the German Weather Service (Majewski, 1991) and include parameterizations from the global ECHAM 4 model (Roeckner, 1996). The chemical tracer transport mechanisms include horizontal and vertical advection (Smolarkiewitz, 1983), convective up- and down-draft (Tiedtke, 1989), and vertical diffusion (Mellor and Yamada, 1974). Trace species can undergo chemical decay in the atmosphere or can be removed from the atmosphere by wet and dry deposition or transport out of the model boundaries. Dry deposition is dependent on friction velocities and ground level atmospheric stability (Wesley, 1989). Wet deposition is dependent on precipitation rate, mean cloud water concentration, and compound solubility (Walcek and Taylor, 1986). 158 gasphase reactions from the RADM II photochemical mechanism (Stockwell et al., 1990) are included. 43 longer-lived chemical species are treated as predicted species and 20 shorter-lived ones as diagnosed species. Within the model, sulfate can be produced by the gas phase oxidation of $\mathrm{SO}_{2}$ by $\mathrm{OH}$ or the aqueous phase oxidation of $\mathrm{SO}_{2}$ via five chemical reactions: by $\mathrm{H}_{2} \mathrm{O}_{2}, \mathrm{O}_{3}$, peroxyacetic acid (PAA), methylhydrogenperoxide (MHP), or via catalysis by $\mathrm{Fe}^{3+}$ or $\mathrm{Mn}^{2+}$ (see Walcek and Taylor, 1986, and references therein).

The model was applied with 20 vertical layers of increasing thickness between the Earth's surface and the $10 \mathrm{hPa}$ pressure level (approximately $23 \mathrm{~km}$ ). Analysis data of weather observations from the European Centre for MediumRange Weather Forecasts (ECMWF) were used as boundary conditions every $6 \mathrm{~h}$. The physical and chemical state of the atmosphere was calculated every $5 \mathrm{~min}$. Background concentrations of 39 species (Chang et al., 1987), including $\mathrm{SO}_{2}, \mathrm{SO}_{4}^{2-}, \mathrm{O}_{3}$, and $\mathrm{H}_{2} \mathrm{O}_{2}$, were specified at the lateral model boundaries. The model domain covers Indonesia and Northern Australia $\left(91^{\circ} \mathrm{E}-141^{\circ} \mathrm{E} ; 19^{\circ} \mathrm{S}-8^{\circ} \mathrm{N}\right)$ with a horizontal resolution of $0.5^{\circ}$ (approximately $53 \mathrm{~km}$ in longitude and $55 \mathrm{~km}$ in latitude) with 101 grid points in longitude and 55 grid points in latitude.

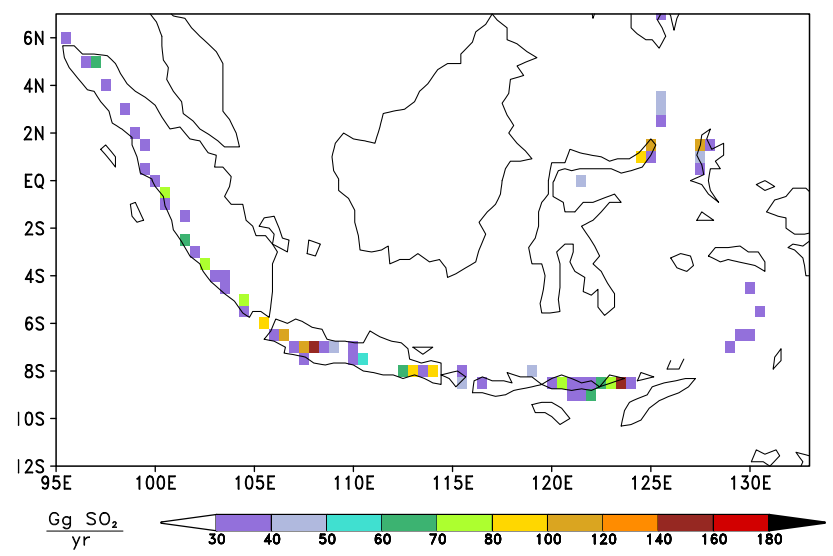

Fig. 1. Emission inventory of the annual sum of continuous (eruptive + passive) and sporadic (eruptive) volcanic $\mathrm{SO}_{2}$ emissions.

\subsection{Emission inventory}

An annual inventory was established to represent maximum potential volcanic emissions within the modeled region of Indonesia (Fig. 1). Over the past century, from 1900 to 1993, 63 volcanoes in Indonesia are known to have erupted and 32 additional volcanoes have degassed passively, for a total sum of 95 active volcanoes (Simkin and Siebert, 1994). The inventory established for this work contains both continuous and sporadic volcanic emissions. Continuous emissions include passive degassing as well as longlasting diffusive eruptive emissions while sporadic emissions include short-lived eruptions (typically stronger than continuously erupted emissions). Continuous emissions were taken from Nho et al. (1996) as this work provides the maximum published estimate of $\mathrm{SO}_{2}$ emissions from the Indonesian volcanoes (Table 1: $1600 \mathrm{Gg} \mathrm{SO}_{2} / \mathrm{yr}$ released non-eruptively; $1900 \mathrm{Gg} \mathrm{SO}_{2} / \mathrm{yr}$ eruptively; for a sum of $3500 \mathrm{Gg} \mathrm{SO}_{2} / \mathrm{yr}$ continuous emissions (which is equivalent to $1750 \mathrm{Gg}(\mathrm{S}) / \mathrm{yr})$ ). The continuous emissions were divided evenly amongst the 95 active volcanoes. This is the most reasonable assumption we could make, despite the fact that emission rates of volcanoes are highly variable in time and between different volcanoes, because only a few of the active Indonesian volcanoes have published $\mathrm{SO}_{2}$ flux measurements. It would have been less reasonable to have scaled the emission flux estimates for individual volcanoes based on the small number of available measurements for the active volcanoes. The division of the continuous emissions between all of the active volcanoes results in a mean continuous $\mathrm{SO}_{2}$ flux of $36.8 \mathrm{Gg} \mathrm{SO}_{2} / \mathrm{yr}\left(100 \mathrm{Mg} \mathrm{SO}_{2} /\right.$ day) for each volcano.

An estimate of the sporadic eruptive volcanic emissions for the region was established for this work using the Simkin and Siebert (1994) catalog of volcanic activity. Simkin and Siebert (1994) provide a compilation of the best known estimates of the date and eruption strength for all of the known volcanic activity on Earth. Each volcanic eruption is 
Table 1. Estimates of Indonesian volcanic emissions.

\begin{tabular}{lrl}
\hline Emission style & $\mathrm{SO}_{2}$ flux $(\mathrm{Gg} / \mathrm{yr})$ & Reference \\
\hline continuous (non-eruptive) & 120 & Hilton et al. (2002) \\
continuous (non-eruptive) & 210 & Spiro et al. (1992) \\
continuous (non-eruptive) & 1600 & Nho et al. (1996) \\
continuous (eruptive) & 1900 & Nho et al. (1996) \\
continuous (eruptive + non-eruptive) & 3500 & sum from Nho et al. (1996) used in this study \\
sporadic (eruptive) & 290 & calculated for this study \\
continuous + sporadic (eruptive + non-eruptive) & $2100-2600$ & Halmer et al. (2002) \\
continuous + sporadic (eruptive + non-eruptive) & 3790 & this study \\
\hline
\end{tabular}

assigned a volcanic explosivity index (VEI) strength which is an indicator of the explosiveness of a volcanic event (Newhall and Self, 1982). All of the eruptions recorded in the catalog during the last century (1900-1993) for each active Indonesian volcano were summed to assemble the sporadic emission inventory. Indexes estimating the amount of $\mathrm{SO}_{2}$ released due to each VEI class have been developed by Schnetzler et al. (1997), the volcanic sulfur index "VSI", and by Halmer et al. (2002), the "modified VSI". In this study, we have applied the VSI. The total number of eruptions of each VEI class was multiplied by the maximum amount of $\mathrm{SO}_{2}$ released by arc volcanoes suggested by the VSI. The $\mathrm{SO}_{2}$ flux resulting from this multiplication was then divided by the 93 years of the record to generate an annual mean emission estimate. Averaging over 93 years removes some of the high natural short-term variability of volcanic activity. These calculations indicate $290 \mathrm{Gg} \mathrm{SO}_{2}$ /yr released sporadically by the Indonesian volcanoes- a sum of sporadic and continuous volcanic emissions of $3800 \mathrm{Gg} \mathrm{SO}_{2} / \mathrm{yr}$ (which is equivalent to $1900 \mathrm{Gg}(\mathrm{S}) / \mathrm{yr})$. The estimated emission fluxes for the individual volcanoes correspond reasonably well with $\mathrm{SO}_{2}$ flux measurements of Indonesian volcanoes (Table 2).

The emissions of each individual volcano were released into the model layer at the actual height of each volcano. The elevations of the volcanoes range from $200 \mathrm{~m}$ (Riang Kotang) to $3805 \mathrm{~m}$ (Kerinci) corresponding to the first 12 model levels.

\subsection{Experiments}

Two experiments were performed: a) "S Experiment"- volcanic $\mathrm{S}$ was released as primarily $\mathrm{SO}_{2}$ that underwent oxidation to $\mathrm{SO}_{4}^{2-}$ following the major tropospheric chemical reactions and b) " $\mathrm{PbCl}_{2}$ Experiment" - $\mathrm{PbCl}_{2}$ released as an infinitely soluble passive tracer. The "S Experiment" was conducted to observe the transport and deposition patterns of volcanic $\mathrm{S}: \mathrm{SO}_{2}+\mathrm{SO}_{4}^{2-}$. The volcanic emissions were released into the model as $96 \% \mathrm{SO}_{2}$ and $4 \% \mathrm{SO}_{4}^{2-}$. The assumption of an initial presence of some sulfate at the source to account for immediate oxidation processes is common in atmospheric chemistry modeling (e.g. Stier et al., 2005). Cal- culations have been performed on the results of the " $\mathrm{S}$ Experiment" to determine atmospheric $\mathrm{SO}_{2}$ loss rates from the volcanic plumes. $\mathrm{SO}_{2}$ loss rate is a function of the concentration of $\mathrm{SO}_{2}$ at two locations within a volcanic plume, the distance between these two locations, and the time of travel from the first to the second location. The calculations have been performed in order to replicate the analysis of field measurements of tropospheric $\mathrm{SO}_{2}$ loss rates at individual volcanoes (Oppenheimer et al., 1998).

$\mathrm{SO}_{2}$ loss rate from the model results was calculated as follows: over a given time period (year or season), the mean wind direction of each gridbox containing a volcano "V" was used to define which of the 8 surrounding gridboxes in the horizontal directions the $\mathrm{SO}_{2}$ was most likely to be transported to: "V+1". This was repeated a second time to define the gridbox "V+2", a distance of 55-200 km (average $120 \mathrm{~km}$ ) away from the volcano. The mean column burden, or the total mass per area of the given species contained in the entire atmospheric vertical column (up to the top of the model, $10 \mathrm{hPa}$ ), of $\mathrm{SO}_{2}$ at "V" and "V+2" were then related following first order kinetics (Eq. 1).

$\Phi_{t_{1}}=\Phi_{t_{2}} e^{k_{1}\left(t_{2}-t_{1}\right)}$

where:

$\Phi=$ Column burden at given time $\left[\mathrm{kg} / \mathrm{m}^{2}\right]$

$t_{2}-t_{1}=$ time to be transported from location 1 to 2 [s]

$k_{1}=\mathrm{SO}_{2}$ loss rate $\left[\mathrm{s}^{-1}\right]$

The mean wind speed and distance between the two gridboxes were used to calculate the amount of time for transport from "V" to "V+2". The result of the calculation is the yearly or seasonal mean $\mathrm{SO}_{2}$ loss rate " $k_{1}$ " for each volcano. Column burden of $\mathrm{SO}_{2}$ was used in this calculation as opposed to single model level concentrations, as this is a more accurate representation of the data that is obtained by ground-based COSPEC. For some volcanoes, the $\mathrm{SO}_{2}$ loss rate calculation resulted in a negative or null value. A negative value indicates an increase in the concentration of $\mathrm{SO}_{2}$ at " $\mathrm{V}+2$ " compared with "V". This can occur when "V+2" contains $\mathrm{SO}_{2}$ released or transported into the grid box from another 
Table 2. $\mathrm{SO}_{2}$ emissions from individual Indonesian volcanoes.

\begin{tabular}{lrrl}
\hline & $\begin{array}{r}\mathrm{SO}_{2} \text { flux from } \\
\text { emission inventory } \\
(\mathrm{Gg} / \mathrm{yr})\end{array}$ & $\begin{array}{r}\mathrm{SO}_{2} \text { flux from } \\
\text { measurements } \\
(\mathrm{Gg} / \mathrm{yr})\end{array}$ & Reference \\
\hline Volcano & 47.4 & 5.1 & Andres and Kasgnoc (1998) \\
Bromo (Tengger Caldera) & 47.7 & 140.5 & Bluth et al. (1994) \\
Galunggung & & 240.9 & Andres and Kasgnoc (1998) \\
Merapi & 55.6 & 36.5 & Dir. of Volcan. and Geol. Haz. Mit. of Indonesia (2005) \\
& & 51.1 & Andres and Kasgnoc (1998) \\
Slamet & & 73.0 & LeGuern (1982) \\
Tangkubanparahu & 45.4 & 21.2 & Nho et al. (1996) \\
& 37.5 & 27.4 & Andres and Kasgnoc (1998) \\
\hline
\end{tabular}

volcano. A null value can occur when the wind direction is so variable that the emissions are predicted in the first step to be transported away from the grid box " $\mathrm{V}$ " and in the second step returned to it, for a net distance of 0 . In both of these situations, the calculated $\mathrm{SO}_{2}$ loss rates have been excluded from further consideration.

The " $\mathrm{PbCl}_{2}$ Experiment" was conducted to observe the transport and deposition pattern of $\mathrm{PbCl}_{2}$, a highly soluble compound released by volcanoes in relatively large concentrations (e.g. Delmelle, 2003). As $\mathrm{PbCl}_{2}$ is not among the chemicals originally included in REMOTE, we included $\mathrm{PbCl}_{2}$ in the model as an infinitely soluble passive tracer. $\mathrm{PbCl}_{2}$ (solubility $=0.99 \mathrm{~g} / 100 \mathrm{cc}$ CRC Handbook, 1993) is very soluble, and not infinitely soluble, so the modeling assumption of infinite solubility will lead to a slight overprediction of the solubility of $\mathrm{PbCl}_{2}$. The $\mathrm{PbCl}_{2}$ is released as a passive tracer, and as such it is transported in the atmosphere and is removed from the atmosphere by wet and dry deposition processes, but it does not react to form other chemical species. The emission inventory was established for volcanic $\mathrm{SO}_{2}$, so to calculate a corresponding emission flux of $\mathrm{PbCl}_{2}$ the emissions have been scaled to the ratio of $\mathrm{Pb}$ to $\mathrm{S}$ in Indonesian fumarolic gases (Table 3), which may produce an underestimation of the flux of the volcanic $\mathrm{PbCl}_{2}$, as described earlier.

\section{Results}

The results of the "S Experiment" are presented first, followed by the $\mathrm{SO}_{2}$ loss rates that have been calculated from these results. The results of the " $\mathrm{PbCl}_{2}$ Experiment" are presented last.

\section{1 "S Experiment" and calculated $\mathrm{SO}_{2}$ loss rates}

The modeled atmospheric distribution of volcanic $\mathrm{S}$ species is shown as annual mean column burden in Fig. 2 as a) $\mathrm{SO}_{2}$, b) $\mathrm{SO}_{4}^{2-}$, and c) total volcanic $\mathrm{S}\left(\mathrm{SO}_{2}+\mathrm{SO}_{4}^{2-}\right)$. The atmo-

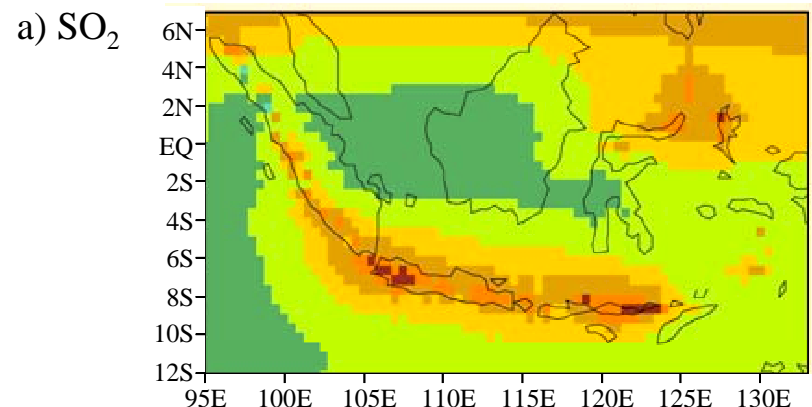

b) $\mathrm{SO}_{4}{ }^{2-}$
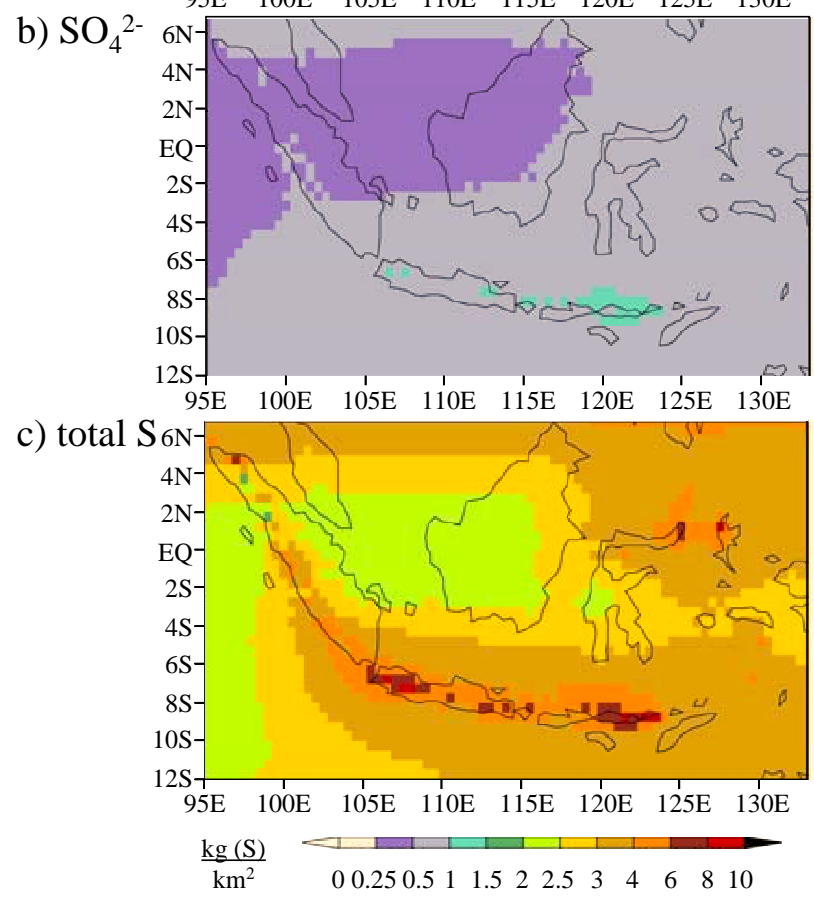

Fig. 2. Annual mean vertical column burden of (a) $\mathrm{SO}_{2}$, (b) $\mathrm{SO}_{4}^{2-}$, and (c) total $\mathrm{S}: \mathrm{SO}_{2}+\mathrm{SO}_{4}^{2-}$ for the "S Experiment".

spheric concentration of $\mathrm{SO}_{2}$ is much higher than that of $\mathrm{SO}_{4}^{2-}$, and dominates the sum of the two. The annual mean 
Table 3. $\mathrm{Pb} / \mathrm{S}$ ratios in Indonesian volcanic gases.

\begin{tabular}{lrl}
\hline Volcano & $\mathrm{Pb} / \mathrm{S}(\mu \mathrm{g} / \mathrm{g})$ & Reference \\
\hline Merapi & 420 & Nho et al. (1996) \\
Merapi & 35 & Symonds et al. (1987) \\
Papandayan & 280 & Nho et al. (1996) \\
Mean & 245 & the average of the above measurements was applied in this study \\
Global mean & 190 & Hinkley et al. (1999) \\
\hline
\end{tabular}

a) $\mathrm{SO}_{2}$

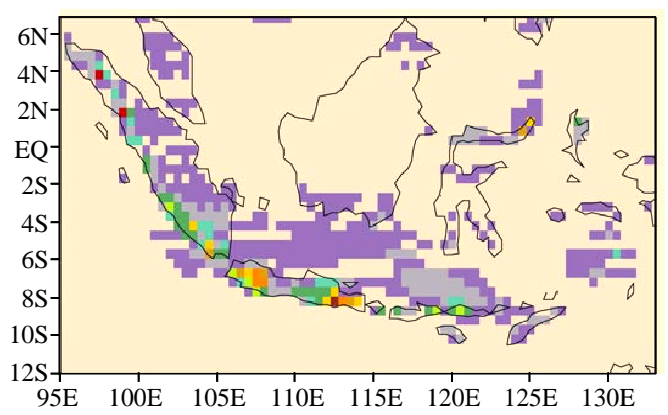

b) $\mathrm{SO}_{4}{ }^{2-}$

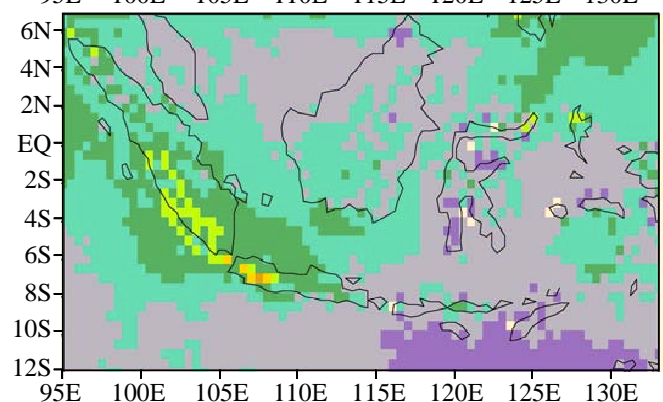

c) total $\mathrm{S}$

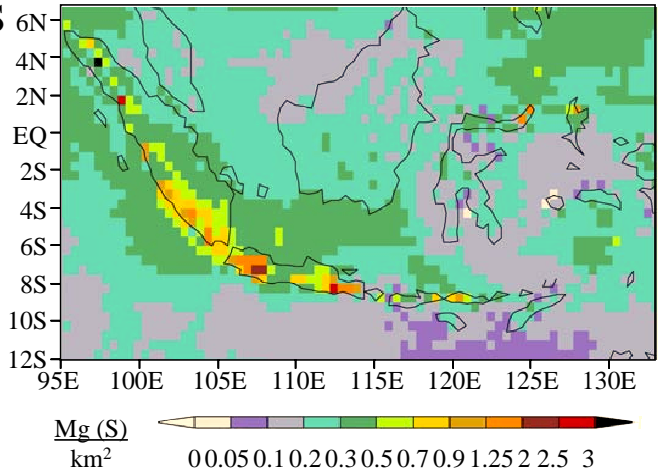

Fig. 3. Annual sum of the (a) dry $\mathrm{SO}_{2}$ deposition, (b) dry + wet $\mathrm{SO}_{4}^{2-}$ deposition, and (c) total $\mathrm{S}$ : dry $\mathrm{SO}_{2}+$ dry + wet $\mathrm{SO}_{4}^{2-}$ deposition for the "S Experiment".

column burden of $\mathrm{SO}_{2}$ ranges from $1.5-10 \mathrm{~kg}(\mathrm{~S}) / \mathrm{km}^{2}$ and $\mathrm{SO}_{4}^{2-}$ from $0-1.5 \mathrm{~kg}(\mathrm{~S}) / \mathrm{km}^{2}$. Qualitatively, both $\mathrm{SO}_{2}$ and $\mathrm{SO}_{4}^{2-}$ show the highest concentrations near to the volcanoes, while away from the volcanoes the concentration decreases, with the dominant transport away from the volcanoes towards the east. Relatively high atmospheric concentrations of the $\mathrm{S}$ species are also seen at the northern boundaries of

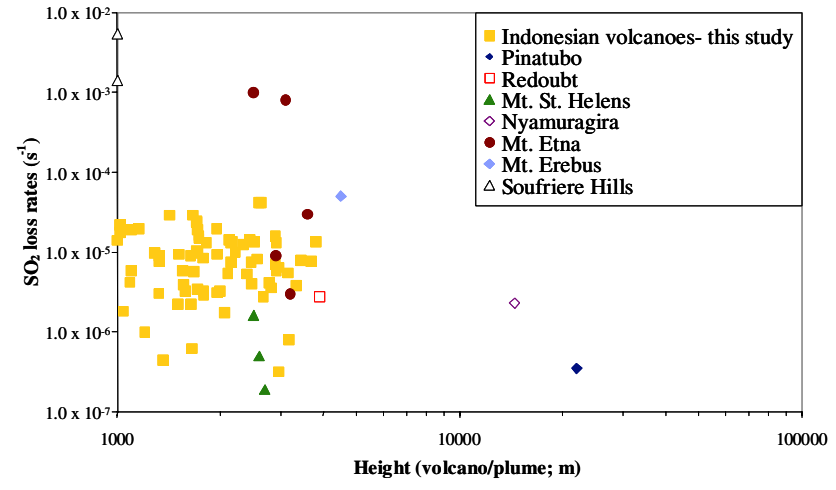

Fig. 4. Modeled $\mathrm{SO}_{2}$ loss rates (yellow squares) are plotted against the actual height of each volcano and measured $\mathrm{SO}_{2}$ loss rates from Oppenheimer et al. (1998) are plotted against the observed plume height.

the figures. This is a result of the concentrations of $\mathrm{SO}_{2}$ and $\mathrm{SO}_{4}^{2-}$ defined at the boundaries of the model domain to represent input from pollution from outside the modeled region and is not a result of the transport of volcanic $S$.

Volcanic $\mathrm{S}$ deposition is presented as a) the annual sum of the dry $\mathrm{SO}_{2}$ deposition, b) dry + wet $\mathrm{SO}_{4}^{2-}$ deposition, and c) the total volcanic $\mathrm{S}$ deposition as the sum of the two (Fig. 3). More than $99 \%$ of $\mathrm{SO}_{4}^{2-}$ is deposited via wet deposition, so only the total $\mathrm{SO}_{4}^{2-}$ deposition is shown. $\mathrm{SO}_{2}$ is dry deposited in large concentrations close to the volcanoes, up to $3 \mathrm{Mg}(\mathrm{S}) / \mathrm{km}^{2}$, but with almost no deposition away from the volcanoes. $\mathrm{SO}_{4}^{2-}$, in comparison, has a maximum annual deposition of only up to $1.25 \mathrm{Mg}(\mathrm{S}) / \mathrm{km}^{2}$, with much more significant deposition away from the volcanoes. $83 \%$ of the volcanic $\mathrm{S}$ is deposited as $\mathrm{SO}_{4}^{2-}$. There is an average annual sum of deposition over the entire modeled region of $45.6 \mathrm{~kg}(\mathrm{~S}) / \mathrm{km}^{2} \mathrm{SO}_{2}$ and $219.6 \mathrm{~kg}(\mathrm{~S}) / \mathrm{km}^{2} \mathrm{SO}_{4}^{2-}$.

The $\mathrm{SO}_{2}$ loss rates calculated from the model results $\left(3.2 \times 10^{-7}-4.1 \times 10^{-5} \mathrm{~s}^{-1}\right)$ agree well in magnitude with $\mathrm{SO}_{2}$ loss rates measured at individual volcanoes in other parts of the world $\left(1.9 \times 10^{-7}-5.4 \times 10^{-3} \mathrm{~s}^{-1}\right)$ (Fig. 4) (Oppenheimer et al., 1998). There is a large variability in $\mathrm{SO}_{2}$ loss rates measured at different volcanoes, and at Mt. Etna alone, $\mathrm{SO}_{2}$ loss rates have been observed to vary over 3 orders of magnitude. 


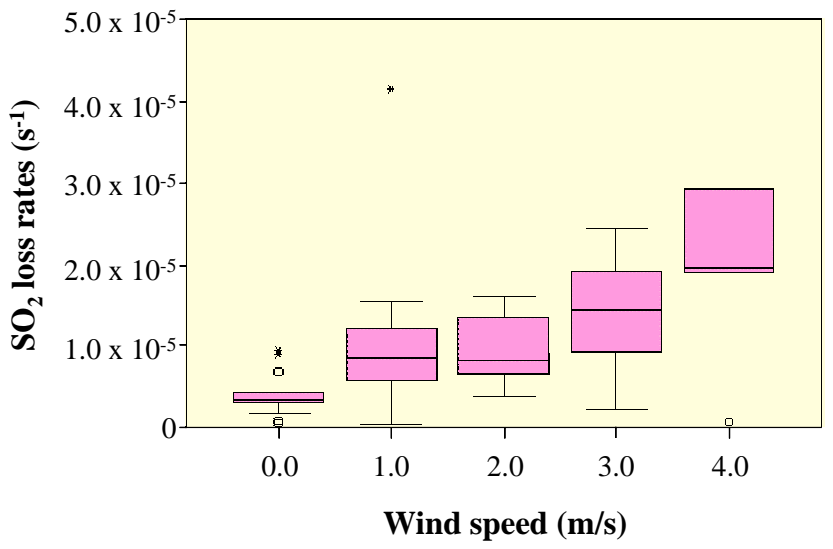

Fig. 5. Annual mean $\mathrm{SO}_{2}$ loss rates for each modeled volcano plotted against the annual mean wind speed at the height of each volcano.

Figure 5 shows a box plot of the bin wind speed over $1 \mathrm{~m} / \mathrm{s}$ intervals plotted against $\mathrm{SO}_{2}$ loss rates. The lower edge of the box represents the 25th percentile value and the upper edge the 75 th. The height of each box shows the interquartile range for each bin and is an indicator of the variability of the values. The line across the box indicates the median (50th percentile). Four outlayer values are shown as open circles and three extreme values as stars. The correlation between windspeed and $\mathrm{SO}_{2}$ loss rate is weak but statistically significant $\left(p<0.01 ; R^{2}=0.2\right)$. There is a general trend of increasing wind speed associated with increased $\mathrm{SO}_{2}$ loss rates as well as an increase in the variability of the $\mathrm{SO}_{2}$ loss rates. Temperature and relative humidity, in contrast, demonstrate trivial and non-significant $\left(R^{2}<0.02\right)$ correlation with $\mathrm{SO}_{2}$ loss rate. It was relevant to look for a correlation with temperature and relative humidity because these meteorological parameters influence the pathways of $\mathrm{SO}_{2}$ to $\mathrm{SO}_{4}^{2-}$ formation as well as precipitation, which influences removal processes.

$\mathrm{SO}_{2}$ loss rates have been calculated for each month and season based on the monsoonal winds: north monsoon (December-March); April/May intermonsoon (April-May); south monsoon (June-September); and October/November intermonsoon (October-November). The north monsoon is distinguished by winds blowing predominantly from China, the south monsoon by winds blowing predominantly from the Indian Ocean and Australia, and the intermonsoon seasons are distinguished by weak and variable direction winds. $\mathrm{SO}_{2}$ loss rates as a function of season are shown as a box plot in Fig. 6. Three outlayer values are shown as open circles and one extreme value as a star. The only seasons with outlayers and extreme values are the two monsoon seasons. Excluding the outlayers and extremes, winter has the lowest variability and spring the highest. The mean seasonal $\mathrm{SO}_{2}$ loss rates for all volcanoes vary between $9.7 \times 10^{-6} \mathrm{~s}^{-1}$ (April/May) and $1.3 \times 10^{-5} \mathrm{~s}^{-1}$ (south monsoon). A greater variability is demonstrated between individual volcanoes than between

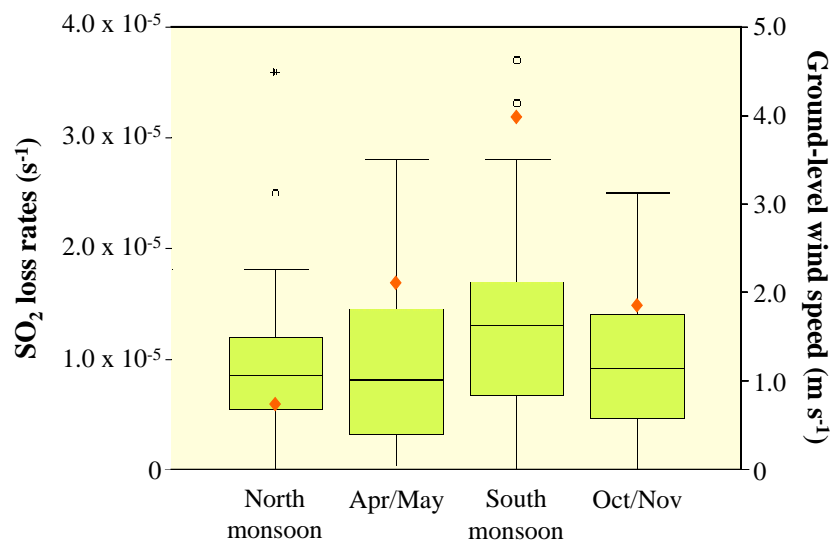

Season

Fig. 6. Seasonal $\mathrm{SO}_{2}$ loss rates (green boxes) and mean groundlevel wind speeds (orange diamonds).

the seasonal means averaged over all of the volcanoes. The only season with a significantly higher mean $\mathrm{SO}_{2}$ loss rate is the south monsoon, which is distinguished by the strongest wind speed.

Loss of volcanic $\mathrm{SO}_{2}$ from the atmosphere can be accomplished via the dry deposition of $\mathrm{SO}_{2}$ and by oxidation to $\mathrm{SO}_{4}^{2-}$. There can also be an apparent $\mathrm{SO}_{2}$ loss due to transport outside of the measured plume (in the field) or outside of the predicted transport route (in the calculations performed on the model results). The percentage of $\mathrm{SO}_{2}$ lost due to dry deposition was calculated by dividing the annual mean dry deposition of $\mathrm{SO}_{2}$ for one day by the difference in column burden of $\mathrm{SO}_{2}$ between locations " $\mathrm{V}$ " and " $\mathrm{V}+1$ ", while the percentage of $\mathrm{SO}_{2}$ lost due to oxidation was calculated by dividing the annual mean column burden of $\mathrm{SO}_{4}^{2-}$ in grid box "V" by the difference in column burden of $\mathrm{SO}_{2}$ between locations "V" and "V+1". The remaining lost $\mathrm{SO}_{2}$ was attributed to lateral transport. The average for all volcanoes within an average of $70 \mathrm{~km}$ away from the volcanoes is $53 \%$ of $\mathrm{SO}_{2}$ loss is due to conversion to $\mathrm{SO}_{4}^{2-}, 42 \%$ to dry deposition, and $5 \%$ due to lateral transport. These percentages do not continue at greater distances from the volcanoes. Between locations "V+1" and "V+2" (an average distance of 70-120 km from the volcanoes) the sum of the column burden of $\mathrm{SO}_{4}^{2-}$ and the daily dry deposition of $\mathrm{SO}_{2}$ is greater than the loss of $\mathrm{SO}_{2}$. This apparent incongruity can be explained by the transport of $\mathrm{SO}_{2}$ from other volcanoes into gridbox "V+2". While some sulfate may be transported into box " $\mathrm{V}+2$ ", the transport of sulfate is much less than that of $\mathrm{SO}_{2}$ because of sulfate's high solubility and tendency to be washed out of the atmosphere very quickly. Despite the fact that the percentage loss analysis fails between boxes " $\mathrm{V}+1$ " and " $\mathrm{V}+2$ " due to $\mathrm{SO}_{2}$ from neighboring volcanoes, we have applied the $\mathrm{SO}_{2}$ loss rate equation between points "V" and "V+2" rather than between "V" and "V+1". This is because there is only a small difference in the calculated annual mean $\mathrm{SO}_{2}$ loss rate 


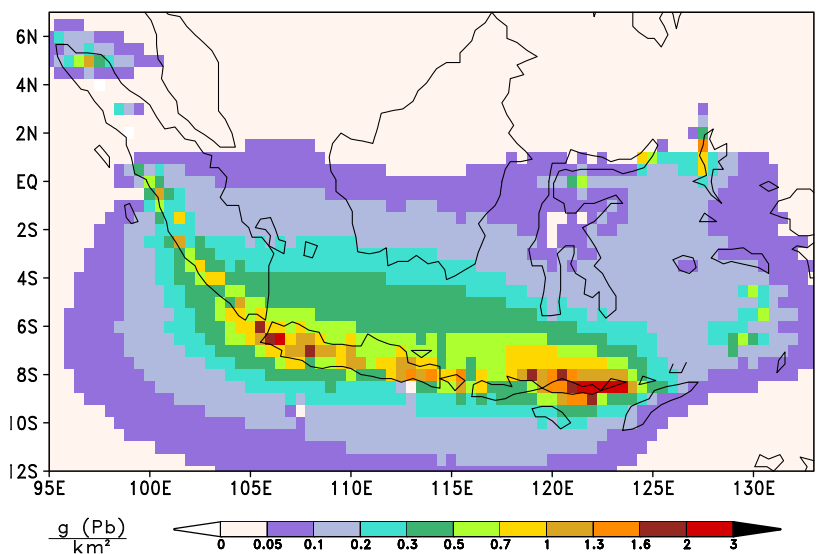

Fig. 7. Annual mean column burden of $\mathrm{PbCl}_{2}$ for the " $\mathrm{PbCl}_{2} \mathrm{Ex}-$ periment".

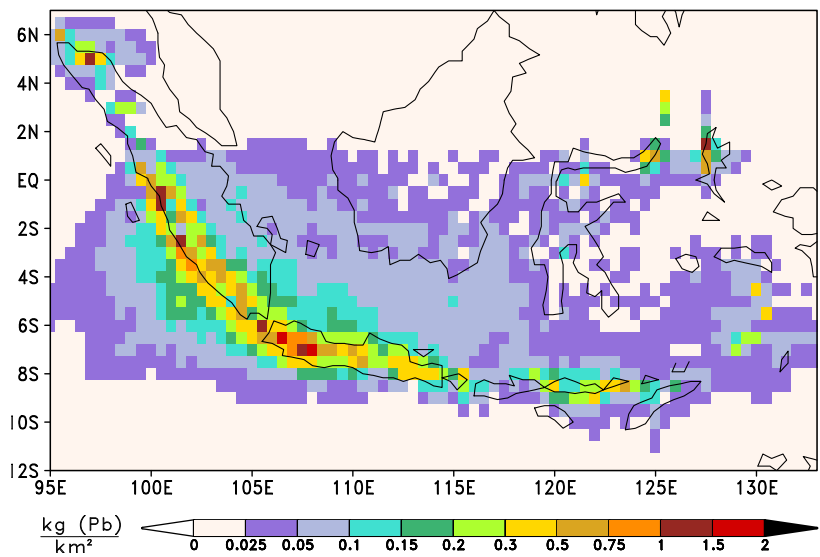

Fig. 8. Annual sum of dry + wet $\mathrm{PbCl}_{2}$ deposition for the " $\mathrm{PbCl}_{2}$ Experiment".

(e-folding rate of 1.3 day versus 1 day) while there is an increase of 1.5 times as many volcanoes that must be excluded from the loss rate calculation between points "V" and "V+1" compared with between " $\mathrm{V}$ " and " $\mathrm{V}+2$ ".

Temperature, relative humidity, and wind speed have been related to the relative percentage of $\mathrm{SO}_{2}$ lost due to the dry deposition of $\mathrm{SO}_{2}$, oxidation to $\mathrm{SO}_{4}^{2-}$, and transport outside of the predicted plume pathway to see if there is any correlation between variations in the meteorological conditions and the manner in which $\mathrm{SO}_{2}$ is lost. No such correlation was found.

\section{$3.2 " \mathrm{PbCl}_{2}$ Experiment"}

The modeled atmospheric distribution of volcanic $\mathrm{PbCl}_{2}$ is shown as annual mean column burden in Fig. 7. The annual mean column burden of $\mathrm{PbCl}_{2}$ ranges from $0-3 \mathrm{~g}(\mathrm{~Pb}) / \mathrm{km}^{2}$. Atmospheric $\mathrm{PbCl}_{2}$ is found in greatest concentrations near to the volcanoes, with only slight easterly transport. The annual sum of the wet and dry $\mathrm{PbCl}_{2}$ deposition is shown in

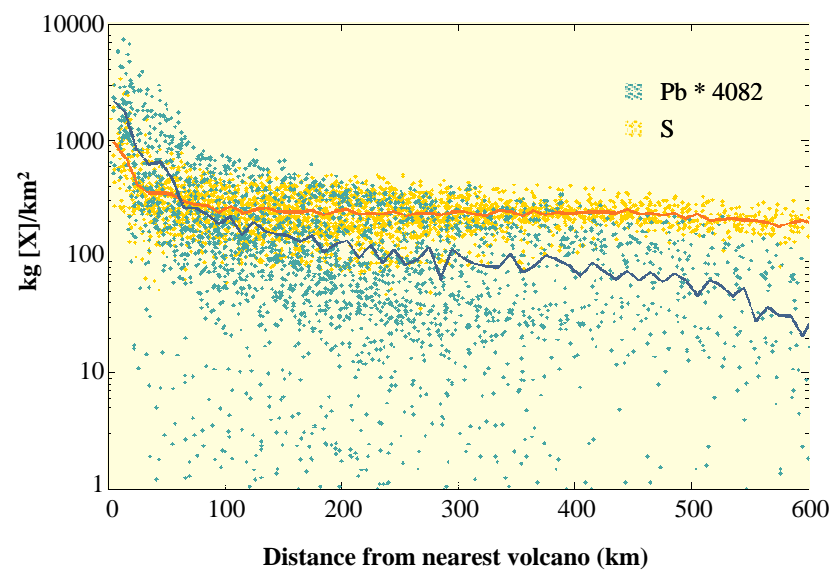

Fig. 9. Annual sum of total deposition for each modeled grid box as a function of the distance to the nearest volcano (" $\mathrm{PbCl}_{2}$ experiment": blue; "S experiment": yellow). The solid lines (corresponding colors) are the bin mean over $10 \mathrm{~km}$ intervals. To show the $\mathrm{S}$ and $\mathrm{Pb}$ on the same scale, the $\mathrm{Pb}$ has been multiplied by 4082 , the inverse ratio of $\mathrm{Pb} / \mathrm{S}$ in Indonesian fumarolic gases.

Fig. 8. More than $99 \%$ of $\mathrm{PbCl}_{2}$ is deposited via wet deposition, so only the sum of the two is presented. The $\mathrm{PbCl}_{2}$ is deposited in concentrations of up to $2 \mathrm{~kg}(\mathrm{~Pb}) / \mathrm{km}^{2}$ with an average annual sum of $52 \mathrm{~g}(\mathrm{~Pb}) / \mathrm{km}^{2}$ of $\mathrm{PbCl}_{2}$ deposited in the modeled region.

Both the atmospheric burden and deposition of $\mathrm{Pb}$ are three orders of magnitude less than that of S. In both experiments, deposition is relatively uniform with relation to distance from any given volcano and not very distinctive for individual volcanoes. We attribute this to the resolution of the model experiments and to the assumption of an even distribution of the continuous volcanic emissions between the active volcanoes. $\mathrm{PbCl}_{2}$ is rapidly deposited very close to the volcanoes, resulting in high local concentrations and a sharp decline in deposition at greater distances from the volcanoes. While $\mathrm{SO}_{2}$ is calculated to have an annual mean loss rate of $1.1 \times 10^{-5} \mathrm{~s}^{-1}$, or an e-folding rate of approximately 1 day, $\mathrm{PbCl}_{2}$ is calculated to have a loss rate of $5.3 \times 10^{-5} \mathrm{~s}^{-1}$, or an e-folding rate of approximately 0.2 day. $\mathrm{SO}_{2}$ is less soluble in rain than $\mathrm{PbCl}_{2}$, and has some dry deposition, but is mostly transported away from the volcanoes prior to conversion to water-soluble $\mathrm{SO}_{4}^{2-}$. Because most of the $\mathrm{SO}_{2}$ is transported and then converted to $\mathrm{SO}_{4}^{2-}$ rather than deposited directly as $\mathrm{SO}_{2}$, there is more $\mathrm{S}$ deposition at increasing distances from the volcanoes compared with $\mathrm{PbCl}_{2}$, creating a less steep gradient of S deposition (Fig. 9), and hence, the larger e-folding rate.

\section{Discussion}

We will interpret the modeling results and discuss how these results can be used to address the two questions described 
above: 1) How do variable meteorological conditions influence volcanic $\mathrm{SO}_{2}$ concentration in the atmosphere and $\mathrm{SO}_{2}$ loss rates? and 2) How do the transport and deposition patterns of highly soluble volcanic compounds relate to $\mathrm{SO}_{2}$ ? After addressing these two questions, we will consider how the volcanic emissions may have influenced the peat forests in the region.

\subsection{Meteorological influences on $\mathrm{SO}_{2}$ loss rate}

The large variabilities of $\mathrm{SO}_{2}$ loss rates measured at individual volcanoes have been attributed to variable atmospheric and plume conditions (Oppenheimer et al., 1998). Our model results suggest, albeit weakly, that the meteorological condition most significantly influencing the variability of $\mathrm{SO}_{2}$ loss rates is wind speed. The suggested relationship between stronger winds and greater $\mathrm{SO}_{2}$ loss rates may indicate an increase in dry deposition at higher winds. Within the model, dry deposition is dependent on turbulence, which is enhanced by stronger winds. We did not find, however, a correlation between increased wind speed and an increased percentage of $\mathrm{SO}_{2}$ lost due to dry deposition. A simpler explanation for the correlation between increased $\mathrm{SO}_{2}$ loss rate and increased wind speed is that given a constant emission rate, stronger winds transport mass away from an emission source more quickly, reducing the concentration of $\mathrm{SO}_{2}$ found at a given distance from a volcano. A relationship between stronger winds and greater variability of $\mathrm{SO}_{2}$ loss rates has been shown. The ramifications of this are that it may be more difficult to obtain a characteristic $\mathrm{SO}_{2}$ loss rate for a volcano that is exposed to highly variable wind conditions, as opposed to a volcano that is exposed to more constant winds.

The environmental conditions in this study are unique for Indonesia. There are a large number of active volcanoes close to each other, potentially resulting in overlapping plumes. The transport of $\mathrm{SO}_{2}$ from other volcanoes into gridboxes under consideration produces a complication for the analysis of the $\mathrm{SO}_{2}$ loss rates. The strong year-round solar radiation promotes the rapid oxidation of $\mathrm{SO}_{2}$ to sulfate and the high rainfall of Indonesia results in the rapid deposition of sulfate. The conclusions drawn in this study about the atmospheric loss of volcanic $\mathrm{SO}_{2}$ are only applicable to this region and should be extrapolated to other volcanic regions cautiously. Further fieldwork-based research that considers variations in wind speed and apparent $\mathrm{SO}_{2}$ loss rates may be able to form a more conclusive statement about the possible correlation between wind speed and $\mathrm{SO}_{2}$ loss rates. It may be important to consider wind speed variations when making interpretations about changes in volcanic activity based on remote $\mathrm{SO}_{2}$ measurements. Some variations in $\mathrm{SO}_{2}$ flux observed over time at one volcano may be due to differences in the winds, as opposed to variations in the volcanic emissions.

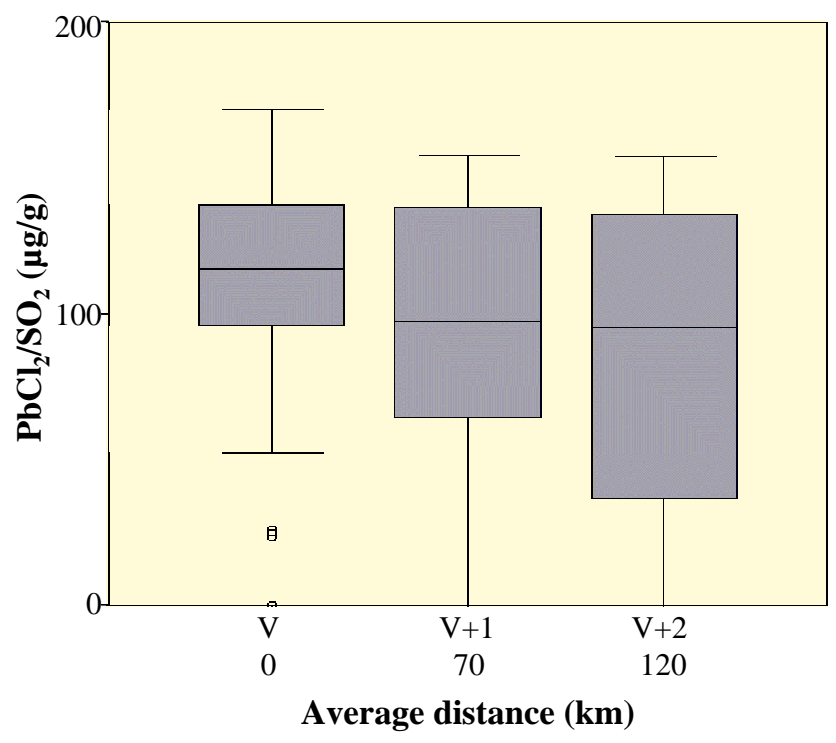

Fig. 10. Annual mean column burden of $\left[\mathrm{PbCl}_{2}\right] /\left[\mathrm{SO}_{2}\right]$ for all volcanoes plotted against the mean distance from each volcano $(\mathrm{km})$ for locations "V", "V+1", and "V+2".

\subsection{Differences in transport and deposition patterns due to solubility}

The influence of solubility on deposition patterns is illuminated by comparing the results of the two performed experiments (Fig. 9). The dependency of deposition rate on solubility has implications for the accurate extrapolation of measurements of $\mathrm{SO}_{2}$ flux in aged volcanic plumes to other compounds. The further away from a volcano such measurements are made, the less accurate it is to assume that the concentration of volcanic $\mathrm{SO}_{2}$ measured there has the same ratio to more soluble species as the ratio measured in fumarolic gases.

The ratio of $\left[\mathrm{PbCl}_{2}\right] /\left[\mathrm{SO}_{2}\right]$ in the air decreases with increasing distance from the volcanoes as the $\mathrm{PbCl}_{2}$ is deposited (Fig. 10). Figure 10 is a box plot with the same specifics as for Figs. 5 and 6. Four outlayer values are shown as open circles at location "V". The interquartile range increases at greater distance from the volcanoes indicating that the variability of the $\left[\mathrm{PbCl}_{2}\right] /\left[\mathrm{SO}_{2}\right]$ ratio is growing at greater distances from the volcanoes. The median $\left[\mathrm{PbCl}_{2}\right] /\left[\mathrm{SO}_{2}\right]$ ratio decreases exponentially at greater distances from the volcanoes with the mean exponential rate of decay of the $\left[\mathrm{PbCl}_{2}\right] /\left[\mathrm{SO}_{2}\right]$ ratio based on these three distances being $y=106.5 e^{-0.002 x}$.

where:

$y=\left[\mathrm{PbCl}_{2}\right] /\left[\mathrm{SO}_{2}\right](\mu \mathrm{g} / \mathrm{g})$

$x=$ distance from volcanoes $(\mathrm{km})$.

The mean $\left[\mathrm{PbCl}_{2}\right] /\left[\mathrm{SO}_{2}\right]$ ratio at the three distances are: "V"=107.7; "V+1"=89.3; and "V+2"=83.2 $\mu \mathrm{g} / \mathrm{g}$. The ratio 


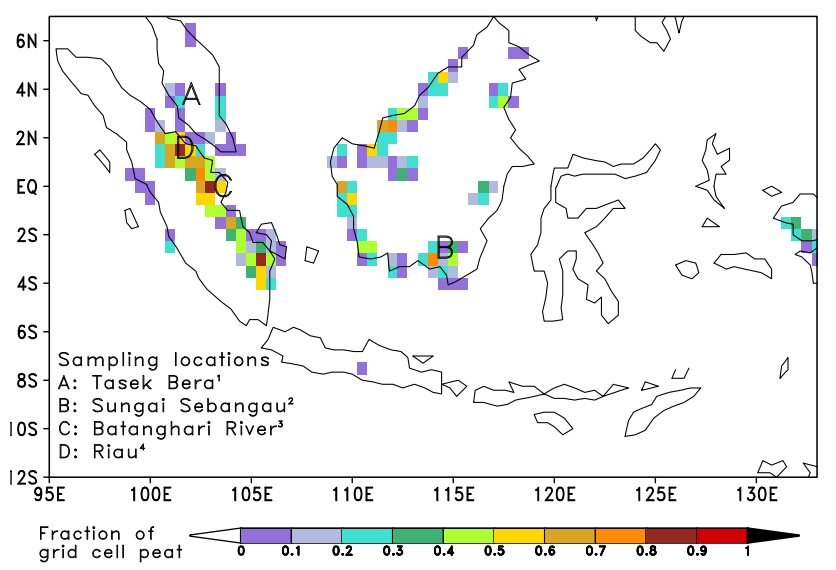

Fig. 11. Peat sampling locations on a map of the fractional peat coverage of the modeled region (after Heil et al., 2005). ${ }^{1}$ Wüst and Bustin (2001); ${ }^{2}$ Weiss et al. (2002); ${ }^{3}$ Esterle and Ferm (1994); 4 Supardi et al. (1993).

of $107.7 \mu \mathrm{g} \mathrm{PbCl}_{2} / \mathrm{g} \mathrm{SO}_{2}$ is equivalent to $160.5 \mu \mathrm{g} \mathrm{Pb} / \mathrm{g} \mathrm{S}$. This differs from the $245 \mu \mathrm{g} \mathrm{Pb} / \mathrm{g} \mathrm{S}$ defined as the ratio of $\mathrm{Pb} / \mathrm{S}$ in the primary volcanic emissions (Table 3 ) because of $\mathrm{SO}_{2}$ released by other volcanoes and transported into gridbox "V".

Based on this mean rate of decay, we estimate that calculations (e.g. based on COSPEC measurements) which assume a constant $[\mathrm{X}] /[\mathrm{S}]$ ratio as found in fumarolic gases will result in a $6 \%$ underestimation of the emission flux of highly soluble species at $30 \mathrm{~km}$ distance away from a volcanic vent; at $100 \mathrm{~km}$, this would grow to an $18 \%$ underestimation. Our results indicate that the assumption of a constant ratio between $\mathrm{SO}_{2}$ and other, highly soluble species such as $\mathrm{PbCl}_{2}$ is justified at distances where COSPEC is usually performed.

\subsection{Comparison between modeled $\mathrm{S}$ deposition and peat core samples}

We have used the modeling results to examine the hypothesis proposed by Langmann and Graf (2003) that the Indonesian volcanic emissions have had a significant influence on the sulfur content of peat in the area. In order to assess the potential contribution of volcanic emissions to the sulfur content of Indonesian peat, we have compared the modeled S deposition with the concentration of $\mathrm{S}$ measured in peat core samples collected in the modeled region. Peat can serve as a historical record of atmospheric deposition for time periods of up to thousands of years. The peat areas of Indonesia may be particularly useful recorders of the deposition of volcanic emissions because of the large number of historical and modern active volcanoes in the vicinity of peat areas (Langmann and Graf, 2003). It has been suggested in several studies that anomalous, high concentrations of $\mathrm{S}$ and other chemicals including $\mathrm{Pb}$ in peat core samples (collected outside of Indonesia) may be due to volcanic deposition (e.g. Weiss et al.,
1997; Roos-Barraclough et al., 2002; Kylander et al., 2005). Within Indonesia, there are two main types of peat: ombrogenous and topogenous (Page et al., 1999). Ombrogenous peat receives nutrients only from atmospheric deposition while topogenous peat also receives nutrients from groundwater. Ombrogenous peat is therefore more useful for interpreting the historical deposition of atmospheric compounds. In this work we have compiled measurement data from the literature of $\mathrm{S}$ in four ombrogenous peat areas in Indonesia for comparison with the modeled S deposition (Fig. 11; Table 4).

The average $S$ of each sampled peat core was calculated by multiplying the average percent $S$ in each of the four peat sampling locations with the average peat dry bulk density $\left(0.18 \mathrm{~g} / \mathrm{cm}^{3}\right)$ given by Shimada et al. (2001). This value was multiplied by the minimum $(1.7 \mathrm{~mm} / \mathrm{yr})$ and maximum $(4.3 \mathrm{~mm} / \mathrm{yr})$ peat accumulation rates provided by Supardi et al. (1993), resulting in the presented range of values for the $\mathrm{S}$ deposition of each peat core. The average \% $\mathrm{S}$ was calculated from 3-16 samples within each peat core. Peat core samples had both total $\mathrm{S}$ and ${ }^{14} \mathrm{C}$ age measured, or had only total $\mathrm{S}$ measured and were very close to another peat sample where ${ }^{14} \mathrm{C}$ was measured. $\mathrm{S}$ values from portions of the peat cores that were dated to be less than 150 years old were not included in the average as these $\mathrm{S}$ values may have been influenced by human activity.

A comparison between the modeled $\mathrm{S}$ deposition and the rate of $\mathrm{S}$ deposition measured in the peat core samples reveals values with the same orders of magnitude (Table 4). The potential volcanic contribution to the peat $\mathrm{S}$ has been calculated on the basis of what percentage of the peat $S$ could be attributed to the deposition of volcanic $S$. We find that $6-72 \%$ of the $S$ measured in the peat samples could have volcanic origin. There is a relatively uniform concentration of volcanic $\mathrm{S}$ predicted to be deposited on all four peat areas $\left(215-285 \mathrm{~kg} / \mathrm{km}^{2}-\mathrm{yr}\right)$. This is because of the distance between the peat areas and the nearest volcanoes (minimum $153 \mathrm{~km}$ ) and the relatively homogeneous modeled deposition of $\mathrm{S}$ at these distances from the volcanoes. It would be helpful to be able to compare the model results with a peat sample collected nearer to the volcanoes, but we have not been able to obtain such a sample. We find the agreement in scale to be a strong indication that the modeled deposition of the volcanic $\mathrm{S}$ is reasonable.

Our modeling results indicate that the Indonesian volcanoes have contributed slightly to the quantitative sulfur content of peat in the region. This does not suggest that the volcanic $\mathrm{S}$ has little qualitative contribution to the the peat's characteristics. Sulfur cycling within peat is complicated, and peat is not a closed system. Moore et al. (2004) have found that approximately $75 \%$ of anthropogenic $\mathrm{S}$ deposited onto peat in eastern Canada is accumulated within the peat. This value may differ depending on the different origins of the $\mathrm{S}$, such as volcanoes, sea spray, and anthropogenic pollution, as this may dictate the state of the deposited S. Thompson and Bottrell (1998) have demonstrated that Sphagnum, 
Table 4. The letters in parenthesis refer to the sampling locations marked in Fig. 11 Comparison of modeled $\mathrm{S}$ deposition and peat core samples.

\begin{tabular}{llrrrl}
\hline $\begin{array}{l}\text { Sampling } \\
\text { location }\end{array}$ & $\begin{array}{l}\text { Distance to } \\
\text { nearest } \\
\text { volcano }(\mathrm{km})\end{array}$ & $\begin{array}{r}\text { Measured S } \\
\text { accumulation } \\
\left(\mathrm{kg} / \mathrm{km}^{2}-\mathrm{yr}\right)\end{array}$ & $\begin{array}{r}\text { Modeled S } \\
\text { deposition } \\
\left(\mathrm{kg} / \mathrm{km}^{2}-\mathrm{yr}\right)\end{array}$ & $\begin{array}{r}\text { Volcanic S } \\
(\%)\end{array}$ & $\begin{array}{l}\text { Reference } \\
(\% \text { measured } \\
\text { in peat core })\end{array}$ \\
\hline Riau (A) & 153 & $398-1006$ & 285 & $28-72$ & Supardi et al. (1993) \\
Batanghari River (B) & 160 & $1744-4412$ & 264 & $6-15$ & Esterle and Ferm (1994) \\
Tasek Bera (C) & 258 & $796-2012$ & 215 & $11-27$ & Wüst and Bustin (2001) \\
Sungai Sebangau (D) & 396 & $428-1084$ & 253 & $23-59$ & Weiss et al. (2002) \\
\hline
\end{tabular}

a common peat plant in Northern latitude peat areas but not in Indonesia, preferentially incorporates partially reduced sulfur species, and it follows that the source of deposited $\mathrm{S}$ may influence how it is incorporated into Indonesian peat. Within peat, sulfur can be reduced by bacterial activity, given off as $\mathrm{H}_{2} \mathrm{~S}$ gas, and transported downwards and laterally out of the peat dependent on the local hydrology (Novák et al., 2005). This study cannot address how the volcanic S may have influenced the properties of the peat, and a field study incorporating other additional tracers for volcanic activity could shed more light on this question.

\section{Conclusions}

This study demonstrates that realistic modeling of volcanic emissions can lead to an improved understanding of the atmospheric processes occurring in the vicinity of active volcanoes. The results of the study show that $\mathrm{SO}_{2}$ loss rates from the plumes of the Indonesian volcanoes are weakly correlated with wind speed and uncorrelated with relative humidity or temperature and that there is no correlation between these three meteorological phenomena and the relative amount of $\mathrm{SO}_{2}$ lost due to the dry deposition of $\mathrm{SO}_{2}$, conversion to $\mathrm{SO}_{4}^{2-}$, or lateral transport. A relationship is demonstrated between increased wind speed and increased variability of $\mathrm{SO}_{2}$ loss rates. We recommend that further fieldwork-based research be conducted to explore the possible relationship between wind speed and apparent $\mathrm{SO}_{2}$ loss rates as variations in wind speed might lead to changes in $\mathrm{SO}_{2}$ loss rates independent of a change in the state of volcanic activity.

The solubility of the Indonesian volcanic emissions is shown to influence whether they are deposited near to the volcanoes or transported prior to deposition. Highly soluble species such as $\mathrm{PbCl}_{2}$ have high deposition rates near to the volcanoes while the relatively insoluble $\mathrm{SO}_{2}$ is transported away from the volcanoes until it is oxidized to $\mathrm{SO}_{4}^{2-}$ and then rapidly deposited. The ratio of highly soluble species/[ $\left.\mathrm{SO}_{2}\right]$ decreases exponentially at greater distances from the volcanoes. Our results indicate that an assumption of a constant ratio between highly soluble species and $\mathrm{SO}_{2}$ from the fumarole to the distances where COSPEC is usually performed is justified at individual volcanoes. Extrapolating from $\mathrm{SO}_{2}$ measurements to establish global inventories may, however, generate a significant underestimation of the emission rates of highly soluble species, and the solubility effect should be considered.

Acknowledgements. We thank M. Halmer and an anonymous reviewer for their help in focusing the manuscript and making the results clearer. We thank E. Marmer, A. Heil, P. Wetzel, and P. Weis for their help and discussion and for internally reviewing the manuscript. We also thank the German Climate Computing Center (DKRZ) for computer time to run these experiments. MAP was funded by a stipend from the Ebelin and Gerd Bucerius ZEIT Foundation through the International Max Planck Research School on Earth System Modeling.

Edited by: U. Lohmann

\section{References}

Andres, R. J. and Kasgnoc, A. D.: A time-averaged inventory of subaerial volcanic sulfur emissions, J. Geophys. Res., 103(D19), 25 251-25 261, 1998.

Bardintzeff, J.-M. and McBirney, A. R.: Volcanology, second edition, Jones and Bartlett, 2000.

Bluth, G. J. S., Casadevall, T. J., Schnetzler, C. C., Doiron, S. D., Walter, L. S., Krueger, A. J., and Badruddin, M.: Evaluation of sulfur dioxide emissions from explosive volcanism: the 1982-1983 eruptions of Galunggung, Java, Indonesia, J. Volcan. Geotherm. Res., 63, 243-256, 1994.

Bluth, G. J. S., Rose, W. I., Sprod, I. E., and Krueger, A. J.: Stratospheric loading of sulfur from explosive volcanic eruptions, J. Geol., 105, 671-683, 1997.

Chang, J. S., Brost, R. A., Isaksen, S. A., Madronich, S., Middleton, O., Stockwell, W. R., and Walcek, C. J.: A three dimensional Eulerian acid deposition model physical concepts and formulations, J. Geophys. Res., 92, 14 581-14 700, 1987.

Lide, D. R. and Frederikse, H. P. R. (Eds.): CRC Handbook of Chemistry and Physics, CRC Press, 1993.

Delmelle, P.: Environmental impacts of tropospheric volcanic gas plumes, in: Volcanic Degassing, edited by: Oppenheimer, C., Pyle, D. M., and Barclay, J., London, Geol. Soc. Lon., Special Publication, 213, 381-399, 2003. 
Esterle, J. S. and Ferm, J. C.: Spatial variability in modern tropical peat deposits from Sarawak, Malaysia and Sumatra, Indonesia: analogues for coal, Int. J. Coal Geol., 26, 1-41, 1994.

Fujita, S.-i., Sakuri, T., Matsuda, K.: Wet and dry deposition of sulfur associated with the eruption of Miyakejima volcano, Japan. J. Geophys. Res., 108(D15), 4444, doi:10.1029/2002JD003064, 2003.

Graf, H. F., Feichter, J., and Langmann, B.: Volcanic sulfur emissions: Estimates of source strength and its contribution to the global sulfate distribution, J. Geophys. Res., 102(D9), $10727-$ $10738,1997$.

Halmer, M. M., Schmincke, D. J., and Graf, H.-F.: The annual volcanic gas input into the atmosphere, in particular into the stratosphere: A global data set for the past 100 years, J. Volcan. Geotherm. Res., 115, 511-528, 2002.

Halmer, M. M. and Schmincke, H.-U.: The impact of moderatescale explosive eruptions on stratospheric gas injections, Bull. Volcanol., 65, 433-440, 2003.

Heil, A., Langmann, B., and Aldrian, E.: Indonesian peat and vegetation fire emissions: Study on factors influencing large-scale smoke haze pollution using a regional atmospheric chemistry model, Mit. Adapt. Strat. Glob. Ch., doi:10.1007/s11027-0069045-6, 2006.

Hilton, D., Fischer, T. P., and Marty, B.: Noble gases and volatile recycling at subduction zones, in: Reviews in Mineralogy \& Geochemistry - Noble Gases in Geochemistry and Cosmochemistry, edited by: Porcelli, D., Ballentine, C. J., and Weiler, R., Washington D.C., Min. Soc. Am., 47, 319-370, 2002.

Hinkley, T. K., Lamothe, P. J., Wilson, S. A., Finnegan, D. L., and Gerlach, T. M.: Metal emissions from Kilauea, and suggested revision of the estimated worldwide metal output by quiescent degassing of volcanoes, Earth Plan. Lett., 170, 315-325, 1999.

Jacob, D.: A note to the simulation of the annual and inter-annual variability of the water budget over the Baltic Sea drainage basin, Met. Atmos. Phys., 77, 61-73, 2001.

Kylander, M. E., Weiss, D. J., Martínez Cortízas, A., Spiro, B., Garcia-Sanchez, R., and Colesab, B. J.: Refining the preindustrial atmospheric $\mathrm{Pb}$ isotope evolution curve in Europe using an 8,000 year old peat core from NW Spain, Earth Plan. Sci. Lett., 240, 2, 467-485, 2005.

Langmann, B.: Numerical modelling of regional scale transport and photochemistry directly together with meteorological processes, Atmos. Environ., 34, 3585-3598, 2000.

Langmann, B. and Graf, H. F.: Indonesian smoke aerosols from peat fires and the contribution from volcanic sulfur emissions, Geophys. Res. Lett., 30(11), 1547, doi:10.1029/2002GL016646, 2003.

LeGuern, F.: Les débits de $\mathrm{CO}_{2}$ et de $\mathrm{SO}_{2}$ volcaniques dans l'atmosphère, Bull. Volcanol., 45(3), 197-202, 1982.

Majewski, D.: The Europa Modell of the Deutscher Wetterdienst, Sem. Proc. ECMWF, 2, 147-191, 1991.

Mather, T. A., Pyle, D. M., and Oppenheimer, C.: Tropospheric volcanic aerosol, in Robock, A. and Oppenheimer, C., eds: Volcanism and the Earth's atmosphere, Geophysical Monograph 139, Washington D.C., AGU, 189-212, 2003.

McGonigle, A. J. S. and Oppenheimer, C.: Optical sensing of volcanic gas and aerosol emissions, in: Volcanic Degassing, edited by: Oppenheimer, C., Pyle, D. M., and Barclay, J., London, Geol. Soc. Lon., Special Publication 213, 149-168, 2003.
McGonigle, A. J. S., Delmelle, P., Oppenheimer, C., Tsanev, V. I., Delfosse, T., Williams-Jones, G., Horton, K., and Mather, T. A.: $\mathrm{SO}_{2}$ depletion in tropospheric volcanic plumes, Geophys. Res. Lett., 31, L13201, doi:10.1029/2004GL019990, 2004.

Mellor, B. and Yamada, T.: A hierarchy of turbulence closure models for planetary boundary layers, J. Atmos. Sci., 31, 1791-1806, 1974.

Moore, T., Blodau, C., Turunen, J., Roulet, N., and Richard, P. J. H.: Patterns of nitrogen and sulfur accumulation and retention in ombrotrophic bogs, eastern Canada, Gl. Ch. Biol., 11, 356-367, doi:10.1111/j.1365-2486.2004.00882.x, 2004.

Newhall, C. G. and Self, S.: The volcanic explosivity index (VEI): An estimate of explosive magnitude for historical volcanism, J. Geophys. Res., 87, 1231-1238, 1982.

Nho, E.-Y., Le Cloarec, M.-F., Ardouin, B., and Tjetjep, W. S.: Source strength assessment of volcanic trace elements emitted from the Indonesian arc, J. Volcan. Geotherm. Res., 74, 121-129, 1996.

Novák, M., Adomová, M., Wieder, R. K., Bottrell, S. H.: Sulfur mobility in peat, Appl. Geochem., 20, 673-681, 2005.

Nriagu, J. O.: A global assessment of natural sources of atmospheric trace metals, Nature, 338, 47-49, 1989.

Oppenheimer, C., Francis, P., and Stix, J.: Depletion rates of sulfur dioxide in tropospheric volcanic plumes, Geophys. Res. Lett., 25(14), 2671-2674, 1998.

Page, S. E., Rieley, J. O., Shotyk, Ø. W., and Weiss, D.: Interdependence of peat and vegetation in a tropical peat swamp forest, Phil. Trans. R. Soc. Lond., B, 354, 1885-1897, 1999.

Pfeffer, M. A., Rietmeijer, F. J. M., Brearley, A. J., and Fischer, T. P.: Electron microbeam analyses of aerosol particles from the plume of Poás Volcano, Costa Rica and comparison with equilibrium plume chemistry modeling, J. Volcan. Geotherm. Res., 152, 1-2, 174-188, 2006.

Pyle, D. M. and Mather, T. A.: The importance of volcanic emissions for the global atmospheric mercury cycle, Atmos. Environ., 37, 5115-5124, 2003.

Roeckner, E., Arpe, K., Bengtsson, L., Christoph, M., Claussen, M., Duemenis, L., Esch, M., Giorgetta, M., Schlese, M., and Schulzweida, U.: The atmospheric general circulation model ECHAM-4: Model description and simulation of present-day climate, MPI Rep., 218, Hamburg, Germany, 1996.

Roos-Barraclough, F., Martinez-Cortizas, A., García-Rodeja, E., and Shotyk, W.: A 14,500 year record of the accumulation of atmospheric mercury in peat: Volcanic signals, anthropogenic influences and a correlation to bromine accumulation, Earth. Plan. Sci. Lett., 202, 435-451, 2002.

Schnetzler, C. C., Bluth, G. J. S., Krueger, A. J., and Walter, L. S.: A proposed volcanic sulfur dioxide index (VSI), J. Geophys. Res., 102, 20 087-20 092, 1997.

Shimada, S., Takahashi, H., Haraguchi, A., and Kaneko, M.: The carbon content characteristics of tropical peats in Central Kalimantan, Indonesia: Estimating their spatial variability in density, Biogeochem., 53, 3, 249-267, 2001.

Simkin, T.: Terrestrial volcanism in space and time, Annu. Rev. Earth Planet. Sci., 21, 427-452, 1993.

Simkin, T. and Siebert, L.: Volcanoes of the World, 2nd ed., Geoscience Press in association with the Smithsonian Institution Global Volcanism Program, Tucson AZ, 1994.

Smolarkiewitz, P. K.: A simple positive definite advection scheme 
with small implicit diffusion, Month. Weath. Rev., 111, 476-479, 1983.

Spiro, P. A., Jacob, D. J., and Logan, D. J.: Global inventory of sulfur emissions with $1^{\circ} \times 1^{\circ}$ resolution, J. Geophys. Res., 97, 6023-6036, 1992.

Stier, P., Feichter, J., Kinne, S., Kloster, S., Vignati, E., Wilson, J., Ganzeveld, L., Tegen, I., Werner, M., Balkanski, Y., Schultz, M., Boucher, O., Minikin, A., and Petzold, A.: The aerosolclimate model ECHAM5-HAM, Atmos. Chem. Phys., 5, 11251156, 2005, http://www.atmos-chem-phys.net/5/1125/2005/.

Stockwell, W. R., Middleton, P., Chang, J. S., and Tang, X.: The second generation regional acid deposition model: Chemical mechanism for regional air quality modeling, J. Geophys. Res., 95, 16343-16367, 1990.

Stoiber, R. E., Malinconico Jr., L. L., and Williams, S. N.: Use of the correlation spectrometer at volcanoes, in: Forecasting Volcanic Events, edited by: Tazieff, H. and Sabroux, J.-C., Elsevier, 1983.

Supardi, Subekty, A. D., and Neuzil, S. G.: General geology and peat resources of the Siak Kanan and Bengkalis Island peat deposits, Sumatra, Indonesia, in: Modern and Ancient CoalForming, edited by: Cobb, J. C. and Cecil, C. B., Environments, Boulder, CO, Geol. Soc. Am., Special Paper 286, 1993.

Symonds, R. B., Rose, W. I., Reed, M. H., Lichte, F. E., and Finnegan, D. L.: Volatilization, transport and sublimation of metallic and non-metallic elements in high temperature gases at Merapi Volcano, Indonesia, Geoch. Cosmoch. Acta, 51, 20832101, 1987.

Textor, C., Graf, H.-F., Herzog, M., and Oberhuber, J. M.: Injection of gases into the stratosphere by explosive volcanic eruptions, J. Geophys. Res., 108(D19), 4606, doi:10.1029/2002JD002987, 2003.

Thompson, A. and Bottrell, S.: Sulphur isotopic investigation of a polluted raised bog and the uptake of pollutant sulphur by Sphagnum, Env. Pollution, 101, 201-207, 1998
Tiedtke, M.: A comprehensive mass flux scheme for cumulus parameterization in large-scale models, Month. Weath. Rev., 117, 1778-1800, 1989.

Directorate of Volcanology and Geological Hazard Mitigation of Indonesia, http://www.vsi.esdm.go.id/mvo/mvomonitoring.html, 2005.

Walcek, C. J. and Taylor, G. R.: A theoretical method for computing vertical distributions of acidity and sulfate production within cumulus clouds, J. Atmos. Sci, 43, 339-355, 1986.

Weibring, P., Swartling, J., Ednre, H., Svanberg, S., Caltabiano, T., Condarelli, T., Cecchi, G., and Pantani, L.: Optical monitoring of volcanic sulphur dioxide emissions - comparison between four different remote-sensing spectroscopic techniques, Opt. Laser Eng., 37, 267-284, 2002.

Weiss, D., Shotyk, W., Cheburkin, A. K., Gloor, M., and Reese, S.: Atmospheric lead deposition from 12,400 to ca. 2,000 yrs BP in a peat bog profile, Jura Mountains, Switzerland, Water Air Soil Poll., 100, 311-324, 1997.

Weiss, D., Shotyk, W., Rieley, J., Page, S., Gloor, M., Reese, S., and Martinez-Cortizas, A.: The geochemistry of major and selected trace elements in a forested peat bog, Kalimantan, SE Asia, and its implications for past atmospheric dust deposition, Geoch. Cosmoch. Acta, 66, 13, 2307-2323, 2002.

Wesley, M. L.: Parameterization of surface resistances to gaseous dry deposition in regional-scale numerical models, Atmos. Environ., 23, 1293-1304, 1989.

Wüst, R. A. J. and Bustin, R. M.: Low ash peat deposits from a dendritic, intermontane basin in the tropics: A new model for good quality coals, Int. J. Coal Geol., 46, 3-4, 179-206, 2001.

Young, S. R., Voight, B., and Duffell, H. J.: Magma extrusion dynamics revealed by high-frequency gas monitoring at Soufrière Hills volcano, Montserrat, in: Volcanic Degassing, edited by: Oppenheimer, C., Pyle, D. M., and Barclay, J., London, Geol. Soc. Lon., Special Publication 213, 219-230, 2003. 